\title{
Seasonal Analysis of Gateway Prices of Yam in Abia State, Nigeria: A Least Square Dummy Variable Regression Model.
}

\author{
Okoroafor, Ikechukwu Benedict ${ }^{1}$, M.Sc, And Nwabueze, J. Chioma ${ }^{2}$, Ph.D \\ ${ }^{1}$ Pre-ND Program, Federal College of Agriculture, Ishiagu, Ebonyi State, Nigeria \\ ${ }^{2}$ Department of Statistics, Michael Okpara University of Agriculture, Umudike, Abia State Nigeria
}

\begin{abstract}
The main aim of this research work is to construct a statistical model for the determination of gateway prices of yam in Abia State, which could also be used to predict reliable and dependable future price values of yam in Abia State and Nigeria in general. It intends to estimate and isolate trend and seasonal components of time series present in the data, using Least Squares Dummy Variable Analysis Approach. The results obtained showed that monthly dummy variables are all positively related to gateway price of yam, which implies that as the months go by, the gateway prices of yam in Abia State keep increasing in arithmetic progression. Again, the monthly dummy variables are highly statistically significant at 5\% level of significance, meaning that the gateway prices are highly influenced by the months especially, the festive and farming seasons. The deseasonalized values obtained were used to forecast the gateway price value of yam in Abia State, Nigeria for 2011.
\end{abstract}

Key words: deseasonalization, gateway price, yam and Dummy Variable.

\section{Introduction}

Time series in modern times is studied as a stochastic process. A Stochastic process is a family of random variables $X_{t}$ where $t$ is a parameter running over a suitable index set $T$ denoted by $X_{t}, t \in T$. If $T=\{\ldots-1$, $0,1, \ldots\}=Z$, then $X_{t}, t \in Z$ is said to be a discrete parameter process. If $T=\{-\infty, \infty\}$, then $X_{t}, t \in T$ is called a continuous parameter process. Omekara (1995).

Time series as a stochastic process is an ordered sequence of observations (a collection of observations made sequentially in time). Although the ordering is usually through time, particularly in terms of some equally spaced time interval, the ordering may also be taken through other dimensions, such as space. Iwueze (2006).

Many Econometric time series based on monthly or quarterly data exhibits regular seasonal fluctuations or patterns. These fluctuations /patterns are due to some factors. According to Alper and Aruoba (2001), the factors which cause seasonality in Economic time series, have fixed dates according to the Gregorian calendar and their effects on these series can be identified without any difficulty using conventional deseasonalization techniques. In handling time series Econometric Analysis, identifying and eliminating regular seasonal fluctuations from each variable entering the estimation would increase the precision of the coefficient estimates. This is due to two reasons. First, seasonal regularities impose additional variation on variables used in the estimations and second, such fluctuations in general, are not identical across the dependent and independent variables. Alper and Aruoba (2001).

Weather is one of the factors for such fluctuations in Agriculture, Tourism, and Construction etc. Some festive seasons such as Christmas, New Year, Ramadan and Harvest seasons have pronounced influence on the retail trades, especially, prices of farm produce like yam.

According to (Coursey 2001), Yam is a common name for plants of genus Dioscorea of the family of Dioscoreaceae called the yam family. It originated from the tropical areas of three separate continents: Africa, Asia and South America.

Yam is a very important staple food and a major source of energy in the diet of people of West Africa. Nigeria is the World's largest producer of yam (FOA 2008) accounting for over $96 \%$ of the total annual produce of the crop estimated at about 36 - 46 metric tons per annum (Ike and Inoni 2006).

Production of yam has declined over the last few years. This is as a result of various technical, Economic and Social factors, and can be easily explained on the basis of the difficulties encountered not only in growing yams but also in researching the crop. In many yam growing areas, the most serious constraints to productivity are the high cost of planting materials and of labor for field operations (Okoli 1999).

There are many species of yam that are cultivated in both tropical and sub- tropical regions. They are; Dioscorea rotundata (White yam), Dioscorea esculenta (Chinese yam), Dioscorea alata (Water yam) and Dioscorea cayenensis (Yellow yam). Onwueme (1987).

However, the use of seed yam as food as well as planting materials made it costly and unavailable at affordable prices and at the appropriate time (Iwueke 1998). 


\section{Theoretical Framework}

The basic theoretical problems which will be looked into in this work will be based on applying least squares (OLS) and dummy variable in the analysis of seasonal component. Econometrics commonly uses Time series data describing a single entity. Another type of data called Panel data which means any data base describing number of individuals across a sequence of time period (Ahmed and Mohamed 2009). However, for methods that should be used to eliminate seasonal fluctuations and consequences of using different deseasonalization methods on time series properties of a variable see Lovell (1963), hylleberg (1990 and 1992), Metin et al (1997), Francis (2001) and Box and Jenkin (1976) for forecast. Thus, to really utilize the potential value of the information containing the use of dummy variables in seasonal analysis see Gujarati (2006) and Gujarati and Porter (2009).

\section{Data Presentation.}

The purpose of this work is to consider seasonal analysis of gateway prices of yam in Abia State over five (5) years, using dummy variable regression model.

The data used in this study were secondary data from 2006 to 2010 obtained from a survey which covered monthly gateway prices (per $\mathrm{kg}$ ) of yam in Abia State in some rural and urban areas by Abia Agricultural Development Program (ADP). The prices in the rural areas were collected at various rural markets while urban prices were collected at urban markets. The average of the both prices gives the state prices for each month. The areas covered are; Aba, Ikwuano, Bende, Ohafia and Arochukwu.

Gateway price is a reliable means of comparing various goods. When data are segregated by months, we often realize that such series or a combination of factors which may be Economic, Social and or other related Physical factors, which are classified in traditional forms as trend, seasonal, cyclical and irregular variations.

Seasonal component describes periodic fluctuations that occur with about the same intensity each year. Omekara (1995). According to Gujarati and Porter (2009), seasonal component in Time series is a regular oscillatory movement. Often, it is desirable to remove the seasonal factors or components, from a time series so that we can concentrate on the other components such as trend, cyclical and irregular. The process of removing the seasonal component from a time series is known as deseasonalization or seasonal adjustment.

Though, there are several methods of deseasonalization, but this work concentrates only on the method of dummy variable which is given by:

Where

$$
Y_{t}=\alpha_{1} D_{1 t}+\alpha_{2} D_{2 t}+\alpha_{3} D_{3 t}+\ldots+\alpha_{12} D_{12 t}+\mu_{t}
$$

$\mathrm{Y}_{\mathrm{t}}=$ gateway prices of yam.

D's $=$ are the dummies taking a value of 1 in relevant month and 0 , otherwise.

A's $=$ are the differential intercepts.

$\mathrm{t}=$ the month identifier under the following assumptions.

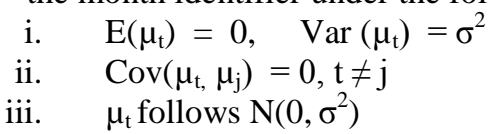

\section{Method Of Analysis}

The data are first plotted graphically to look at the trend movement of the fluctuations in the monthly prices of yam within the period under study. The graph is presented in fig. 1

\section{Ordinary Least Squares (Ols).}

The ordinary least squares (OLS) regression was applied to determine the trend model of gateway prices against the months. Thus, model used is:

$$
\begin{aligned}
Y_{\mathrm{t}} & =\beta_{0}+\beta_{\mathrm{i}} \mathrm{X}_{\mathrm{t}}+\mu_{\mathrm{t}} \\
\mathrm{t} & =1,2,3, \ldots, 60
\end{aligned}
$$

The result of the regression is presented in Table 1

\section{Least Squares Dummy Variables (Lsdv) Regression Models.}

Least squares dummy variable is a method which takes into accounts the individuality of each time (month). The method of assigning a dummy to each month assumes that the seasonal factor, if present is deterministic and not stochastic. This is achieved by allowing the constant to vary for each time periods. To avoid falling into dummy variable trap, January 2006 was used as benchmark month. Hence equation (1) becomes:

$$
Y_{t}=\alpha_{1}+\alpha_{2} D_{2 t}+\alpha_{3} D_{3 t}+\ldots+\alpha_{12} D_{12 t}+\mu_{t}
$$

The results obtained are presented in Table 2. 
However, the deseasonalized time series of gateway prices of yam is obtained by subtracting the estimated value of $\hat{Y}_{t}$ obtained from equation (3) from the actual value of $Y_{t}$, that is

$$
\left(\mathrm{Y}_{\mathrm{t}}-\hat{\mathrm{Y}}_{\mathrm{t}}\right)
$$

The differences obtained from equation (4) simply are the residuals. The results are shown in Table 3.

The forecasted price values for 2011 are therefore obtained by adding the mean (average) of the seasonal components to these residuals, that is:

$$
\left(Y_{t}-\hat{Y}_{t}\right)+Y_{t}
$$

Which are shown in Table 4.

III. Results And Discussions

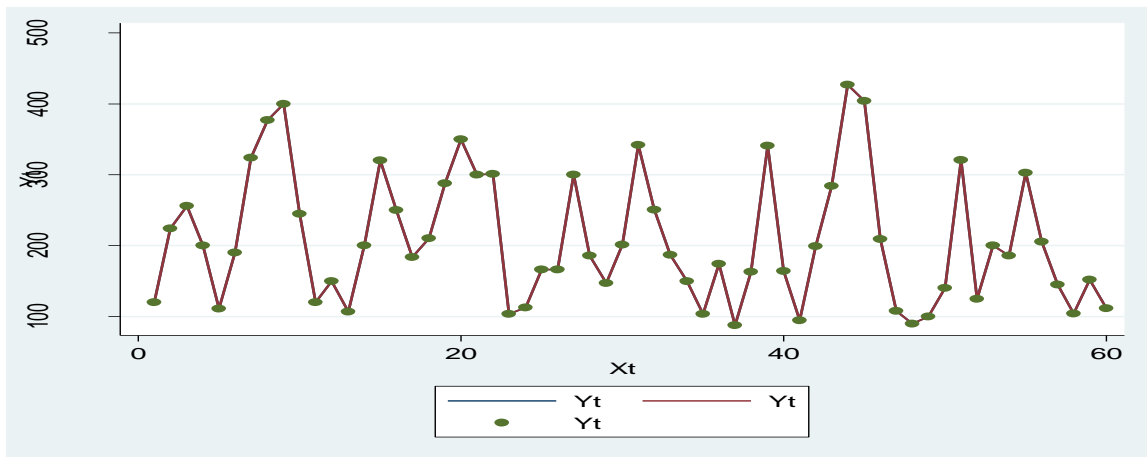

Figure 1: graph of the original data.

TABLE 1: Least Square Model for Fitting Trend (ordinary least squares).

\begin{tabular}{|c|c|c|c|c|c|c|c|}
\hline Source & SS & $d f$ & \multicolumn{2}{|c|}{ MS } & & \multirow{3}{*}{$\begin{array}{l}\text { Number of obs } \\
\text { FC 1, } 58) \\
\text { Prob > F } \\
\text { R-squared } \\
\text { Adj R-squared } \\
\text { Root MSE }\end{array}$} & \multirow{3}{*}{$\begin{array}{r}60 \\
1.94 \\
0.1694 \\
0.0323 \\
0.0156 \\
90.44\end{array}$} \\
\hline $\begin{array}{r}\text { Mode1 } \\
\text { Residua1 }\end{array}$ & $\begin{array}{l}15834.9307 \\
474399.681\end{array}$ & $\begin{array}{r}1 \\
58\end{array}$ & $\begin{array}{l}158 \\
817\end{array}$ & $\begin{array}{l}9307 \\
30485\end{array}$ & & & \\
\hline Total & 490234.612 & 59 & 830 & 06122 & & & \\
\hline$Y t$ & Coef. & std. & Err. & $\mathrm{t}$ & $P>|t|$ & [95\% Conf. & Interva1] \\
\hline $\begin{array}{r}x t \\
\text { _cons }\end{array}$ & $\begin{array}{r}-.9380633 \\
236.6259\end{array}$ & $\begin{array}{r}.6741 \\
23.64\end{array}$ & $\begin{array}{l}899 \\
636\end{array}$ & $\begin{array}{l}-1.39 \\
10.01\end{array}$ & $\begin{array}{l}0.169 \\
0.000\end{array}$ & $\begin{array}{r}-2.287601 \\
189.2926\end{array}$ & $\begin{array}{r}4114745 \\
283.9593\end{array}$ \\
\hline
\end{tabular}
- reg Yt Xt

TABLE 2: Least Squares Dummy Variables (LSDV) Regression Models. - reg Yt D2- D12

\begin{tabular}{|c|c|c|c|c|c|c|}
\hline $\mathrm{Yt}$ & coef. & std. Err. & $t$ & $P>|t|$ & [95\% Conf. & Interva1] \\
\hline $\begin{array}{r}\text { D2 } \\
\text { D3 } \\
\text { D4 } \\
\text { D5 } \\
\text { D6 } \\
\text { D7 } \\
\text { D8 } \\
\text { D9 } \\
\text { D10 } \\
\text { D11 } \\
\text { D12 } \\
\text { _cons }\end{array}$ & $\begin{array}{r}62.52 \\
191.5 \\
68.9 \\
31.1 \\
81.2 \\
192.08 \\
206 \\
171.12 \\
85.72 \\
1.280002 \\
11.56 \\
116.1\end{array}$ & $\begin{array}{r}35.61513 \\
35.61513 \\
35.61513 \\
35.61513 \\
35.61513 \\
35.61513 \\
35.61513 \\
35.61513 \\
35.61513 \\
35.61513 \\
35.61513 \\
25.1837\end{array}$ & $\begin{array}{l}1.76 \\
5.38 \\
1.93 \\
0.87 \\
2.28 \\
5.39 \\
5.78 \\
4.80 \\
2.41 \\
0.04 \\
0.32 \\
4.61\end{array}$ & $\begin{array}{l}0.086 \\
0.000 \\
0.059 \\
0.387 \\
0.027 \\
0.000 \\
0.000 \\
0.000 \\
0.020 \\
0.971 \\
0.747 \\
0.000\end{array}$ & $\begin{array}{r}-9.089015 \\
119.891 \\
-2.709016 \\
-40.50902 \\
9.590984 \\
120.471 \\
134.391 \\
99.51098 \\
14.11098 \\
-70.32901 \\
-60.04902 \\
65.46478\end{array}$ & $\begin{array}{r}134.129 \\
263.109 \\
140.509 \\
102.709 \\
152.809 \\
263.689 \\
277.609 \\
242.729 \\
157.329 \\
72.88902 \\
83.16902 \\
166.7352\end{array}$ \\
\hline
\end{tabular}

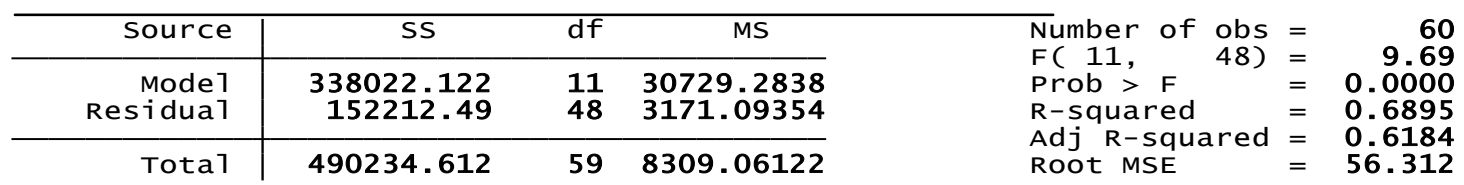


Table 3: Deseasonalized (Residuals)

\begin{tabular}{llllll} 
Monthlyear & 2006 & 2007 & 2008 & 2009 & 2010 \\
\hline JAN & 3.9 & -9.1 & 49.9 & -28.6 & -16.1 \\
FEB & 161.48 & 137.48 & 103.58 & 100.48 & 77.48 \\
MAR & 64.5 & 128.5 & 108.5 & 149.5 & 129.5 \\
APRIL & 131.1 & 181.1 & 117.1 & 95.1 & 56.1 \\
MAY & 79.9 & 152.6 & 115.9 & 63.2 & 168.9 \\
JUN & 108.8 & 129.3 & 119.8 & 117.8 & 104.8 \\
JULY & 131.92 & 95.92 & 149.92 & 91.92 & 110.82 \\
AUG & 171 & 144 & 44 & 221 & -0.4 \\
SEPT & 288.88 & 128.88 & 15.88 & 232.88 & -26.02 \\
OCT & 129.1 & 185.1 & 34.1 & 93.1 & -11.8 \\
NOV & 118.72 & 102.12 & 115.72 & 106.72 & 150.82 \\
DEC & 138.44 & 101.04 & 162.74 & 78.44 & 99.84
\end{tabular}

Table 4: Forecasted Gateway Price Values in 2011.

$\begin{array}{lll}\text { Monthlyear } & 2010 & 2011 \\ \text { JAN } & -16.1 & 194.43 \\ \text { FEB } & 77.48 & 288.01 \\ \text { MARCH } & 129.5 & 340.03 \\ \text { APRIL } & 56.1 & 266.63 \\ \text { MAY } & 168.9 & 379.43 \\ \text { JUN } & 104.8 & 315.33 \\ \text { JULY } & 110.82 & 321.35 \\ \text { AUGUST } & -0.4 & 210.13 \\ \text { SEPT } & -26.02 & 184.5 \\ \text { OCT } & -11.8 & 228.91 \\ \text { NOV } & 150.82 & 361.35 \\ \text { DEC } & 99.84 & 310.37\end{array}$

Figure 1 shows that there are upward and downward trend movements in the price values of yam in Abia State, showing that there is a seasonal fluctuation or pattern in the data associated with the various months.

Table 1 is the trend model. It shows that the gateway price value of yam in Abia State is negatively related to time (months). It revealed that for an increase years, the gateway price value of yam in Abia State decreases by 0.938 units.

Table 2 shows that all the monthly dummy coefficients have positive signs a prior to our expectations that gateway price values of yam in Abia State is positively related to or explained by individual months of the year. The Table also revealed that there is a seasonal effect in the price values of yam. This is indicated by the highly statistically significant $t$ values of the dummy coefficients of February, March, April, June, July, August, September and October. This shows that price values of yam in Abia State, Nigeria are relatively high in those months. The significant $t$ value of the dummy coefficients of February, March and April may be because during farming seasons, farmers do purchase available yam as planting materials as well as food. This agrees with the findings of (Iwueke 1998).

Again, the highly significant $\mathrm{t}$ value of the dummy coefficients for June, July, August, September and October revealed that price value of yam is relatively high between June and October every year in Abia State, Nigeria as a result of celebration of new yam festivals. This was in line with (IITA and NRI 2004) that most Households consume yam as an important staple food that constitute about $26 \%$ of the daily calorie intake of Nigerians and that the consumption of yam is in different forms and combinations depending on the socioeconomic and cultural background of the people.

Furthermore, the dummy coefficient of each month gives us the mean gateway price value in each month/season. The coefficients attached to the various dummies are the differential intercepts, showing by how much the average gateway price value in the month that receives a dummy value of 1 differ from that of the benchmark month which is January 2006. 
However, the $\mathrm{R}^{2}$ value of 0.6895 is equally statistically significant indicating that about 68.95 percent of the total variations observed by the dependent variable are accounted for by the independent variables included in the model.

Table 3 shows the deseasonalized series which was obtained from equation (4) while Table 4 shows the forecasted gateway price value of yam for 2011 using the deseasonalized price values for 2010 .

\section{Conclusion}

Proper decomposition of Economic Time series into a trend, seasonal, cyclical and irregular components is essential for an Econometrician to make inference of the unknown population parameters that are of interest to Economic theory. The aim of this research work is to show that for Gateway price value of yam in Abia State and Nigeria in general, least square dummy variable deseasonalization procedure may be applied to remove all deterministic seasonality factors. Abia State a predominantly farmers has been following traditional farming system and seasons in planting as well as harvesting of yam based on the cycle or months of the year. The impact of these events on economic variable may escape the detection of conventional deseaonalization method that search for regular monthly peaks and troughs in the series.

We therefore analyzed the monthly gateway price values of yam in Abia, Nigeria by first linearizing the series and then fit a model which may be used to estimate the trend values. However, the series was deseasonalized using least squares dummy variable regression model to capture the monthly effects on the price values of yam which also were used in forecasting the price of yam in Abia State, Nigeria in 2011. Of the entire monthly dummy variable examined, 8 have significant effect on gateway prices. The estimation results indicate increase in the gateway price value of yam. The significant of these dummies shows that the data used for this study, exhibit conspicuous periodic patterns which reoccur with about the same intensity each year.

\section{References}

[1]. Ahmed, H. Y. and Sobhi, M. R. "A Comparative Study for Estimation Parameters in Panel Data Model”. Journal of Econometrics, 2009, pp $1-15$

[2]. Alper, C. E. and S. B. Aruoba, "Deseasonalizing Macroeconomic Data: A Caveat to Applied Researchers in Turkey" Journal of Econometrics, 2001, pp 1- 17

[3]. Box, G.E.P. and G.M. Jenkins "Time series Analysis Forecasting and Control”. San Francisco: Holden Day 1976.

[4]. Coursey, J. "Production of Improved Planting Materials- Propagated by Seed, Agriculture in the Tropical" Longman, 2001, p264

[5]. Francis, X. D. "Elements of Forecasting" $2^{\text {nd }}$ ed., South- Western Publishing 2001

[6]. Food and Agriculture Organization "Production Year Book Rome", 2008, p 39.

[7]. Gujarati, D. N.(2006), "Essentials of Econometrics" 4 th $e d$. McGraw - Hill, New York.

[8]. Gujarati, D. N. and Porter, D. C. (2009), "Basic Econometrics", $5^{\text {th }}$ ed. McGraw - Hill, New York.

[9]. Hylleberg, S., R. Engle, C. Granger and B. Yoo, "Seasonal Integration and cointegration" Journal of Econometrics, 1990, vol.44, pp $215-238$

[10]. Hylleberg, S. "Modeling Seasonality Advanced Texts in Econometrics", Oxford University Press, New York, 1992 , pp 476.

[11]. Ike, P. C. and Inoni, O. E. "Determinants of Yam Production Economic Efficiency among Small Scale Yam Producer Farmers in Ondo State of Nigeria”, Central European Agriculture, 2006, 7(2) pp337- 342.

[12]. International Institute for Tropical Agriculture and National Resource Institute "On the Bright Side of Yam Production". Retrieved on January 29, 2009 from www.new-ag.info106-3/develop/dev.0.3html.

[13]. Iwueke, C. C. "Appraisal of Yam Mintiset Techniques by Farmers in South - Eastern State of Nigeria, Appropriate Agricultural Technologies for Resource - Poor Farmers”., 1998.

[14]. Iwueze, S. I. "Time Series Analysis in the Time Domain 2006", Abia State University, Uturu Nigeria.

[15]. Lovell, M. "Seasonal Adjustment of Economic Time Series and Multiple Regression Analysis" Journal of the American Statistics Association; 1963 pp993 - 1001

[16]. Metin, K., G. Muradoglu and B. Yazici. "An Analysis of the Day of the Week Effect on the Istanbul Stock Exchange" ISE Review, 1(4), 1997, pp15-25

[17]. Okoli, O. O. "Review of the Development of Minisett Technology for Massive Production of Seed Yam", NRCRI Bulletin 2

[18]. Omekara C.O "An introduction to Time Series",Okigwe: Alvan Publication 1995.

[19]. Onwueme, L. C. "The Tropical Tuber Crops: Yam, Cassava, Sweat Potato and Cocoyam”, John W. K. and sons, 1978, London. 